\title{
ジチオトレイトールの環状ジスルフィド型酸化体 のポーラログラフィー122
}

(1980 年 7 月 21 日. 受 理)

山口整 毅*・塚本務人・千田貢**

pH 2 から 12 の溶液中でジチオトレイトール (DTT) の環状酸化体（trans-1, 2-ジチアン-4, 5-ジ オール, OX-DTT) は水銀電極上で 2 段の還元波を示した。第 1 波 $\left(E_{1 / 2}=-0.430 \mathrm{~V}\right.$ vs. SCE, pH 4.5) は反応律速波の性質を示し，第 2 波 $\left(E_{1 / 2}=-0.91 \mathrm{~V}\right.$ vs. SCE, pH 4.5) は拡散律速波の性質 を示した。交流ポーラログラフィーでは直流第 1 波に対応した電位に非可逆な波 $\left(E_{\mathrm{p}}^{\mathrm{AC}}=-0.460 \mathrm{~V}, \mathrm{pH}\right.$ 4.5）が認められた。直流第 2 波に対応した交流波は認められなかった。その举動の解析からつぎのよ らに結論された。すなわち直流第 1 波の波高を規制しているのは OX-DTT の水銀電極への吸着反応 と考えられ, したがって第 1 波の反応はこの吸着反応につづく吸着した OX-DTT の非可逆な DTT への還元と思われる。直流第 2 波は溶液中の OX-DTT が水銀電極上で非可逆に還元される反応之解 釈された。HMDE を用いる OX-DTT のサイクリックボルタモグラムの挙動は上記の反応機構で解 釈された。また電位掃引の速度が遅い（10 mV/s 以下）ときに現われた不規則な電流の振動の現象は OX-DTT, DTT および DTT の水銀塩の吸着の関与した複雑な酸化-還元反応によるものと思われ る。

\section{1 緒言}

電極材料に水銀を用いたときジスルフィド基は容易に還元され てチオール基を生成するが，他の電極材料たとえば白金を用いた 場合にはこの還元反応が進行し難いことはよく知られている゙๋。 Kolthoff ら4)はポーラログラフ法を用いて水銀電極上におけるシ ステインの酸化反応の検討5) を行ない, 引きつづきシステインの 酸化体であるシスチンの示す還元波の電極反応を検討㬏したが， その結果, シスチンの直流ポーラログラフ波に現われるいわゆる 前置波の電極反応については電極である水銀の接触作用による可 逆な電子授受反応に基づく波であると結論した。

大阪医科大学化学教室, 569 高梘市沢良木町

** 京都大学農学部農芸化学教室, 606 京都市左京区北白川追 分町

1）この報文を“水銀電極上におけるジチトレイトールおよ びその環状シスルフィド型酸化体の挙動(第 2 報)”とす る.

2）前報(第 1 報), 山口整毅, 塚本務人, 千田 貢, 日化, 1980, 722 .

3) M. Brezina, P. Zuman, "Polarography in Medicine, Biochemistry and Pharmacy", Interscience Pub., London (1958) p. 470.

4) I. M. Kolthoff, C. Branum, J. Am. Chem. Soc., 62, 3061(1940).

5) I. M. Kolthoff, C. Branum, ibid., 63, 520(1941).

6) I. M. Kolthoff, W. Stricks, N. Tanaka, ibid., 77, 4739 (1955).

7）管 勇, 小出真次, 黒岩芳郎, 農化， 25，281，325 (1951).
一方, 舘らマは酸化型および還元型のグルタチオンを用いてそ の電極反応を検討した結果（水銀電極上における），グルタチオ ンのチオールージスルフィド基間の酸化-還元反応が非可逆な反応

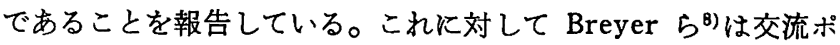
ーラログラフ法を用いてシスチンの直流第 1 波に対応して現われ る交流波の電極反応を検討した結果, 酸化体すなわちシスチンの 水銀電極表面への吸着過程の非可逆性と引きつづく可逆な電子授 受反応を報告している。また最近千田ら ${ }^{9)}$ はリポ酸とその還元体 (ジヒドロリポ酸) の示す酸化-還元反応が可逆性の高い反応であ ることを直流および交流ポーラログラフ法, 定電位電解法などを 用いて確認し, 水銀電極を用いてこの系の標準酸化還元電位の直 接測定を行なった。

著者らは前報2) でジとドロリポ酸と同じジチオール化合物であ るジチオトレイトール(threo-1, 4-ジメルカプト-2, 3-ブタンジオ 一ル，以下 DTT と略記する）の水銀電極上における酸化反沈を 検討したが，DTT のポーラログラフ波（直流第1波）において は DTT の水銀塩が生成していると考えられるにもかかわらず第 1 波の立ち上がり電位よりも数 $\mathrm{mV}$ 正電位側で定電位電解を行 なうと DTT の酸化体 (trans-1, 2-ジチアン-4, 5-ジオール，以 下 OX-DTT と略記する）が生成していることをポーラログラフ 法および分光光度法により確認し，その電極反応について検討し た結果を報告した。本報では前報に引きつづき OX-DTTを用い てその電極反応を検討した。

8) T. Biegler, B. Breyer, Rev. Polarog. (Jpn.), 7, 31 (1959).

9) M. Senda, S. Shibabe, E. Okada, ibid., 14, 392(1967). 


\section{2 装置および試薬}

\section{1 装 置}

直流ボーラログラムの記録には柳本ポーラログラフ P-8 型 （三極式）を用いた。交流波の測定には同社 P 8-AC を付加し， 水銀プールと参照電極である甘コウ電極 (SCE) を $200 \mu \mathrm{F}$ のコ ンデンサーを用いて結合した。滴下水銀電極 (DME) の水銀滴 1 滴の消長についての電流-時間曲線およびサイクリックボルタモ グラムの測定には柳本ボルタンメトリックアナライザー P-1000 型を改造して使用した。用いた DME の特性は $0.1 \mathrm{~mol} / \mathrm{dm}^{3}$ 塩 化カリウム水溶液中で加電圧 $0 \mathrm{~V}$ vs. $\mathrm{SCE}$, 水銀柱 $68 \mathrm{~cm}$ に沶

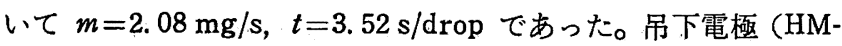
DE) には Metrohm 社製 E-410 型吊下電極を用いだ。電極の表 面積は HMDE に振動を与えて強制的に水銀滴を落下させ，得ら れた滴の重さから電極が球状であると仮定して計算したところ $0.065 \pm 0.008 \mathrm{~cm}^{2}$ であった。試料溶液の $\mathrm{pH}$ 值は Metrohm 社 製 $\mathrm{pH}$ メーター（E-5 R) を用い，ポーラログラム記録直後に湘 定した。特記しないかぎり測定温度は $25 \pm 0.1^{\circ} \mathrm{C}$ とした。

\section{2 試 薬}

OX-DTT は Sigma 社の DTT (DL 体)を用いて Cleland の 方法 ${ }^{(0)}$ にしたがい合成し，その物理的な諸性質はつぎのようであ った。すなわち合成品は $\mathrm{mp} 131.9^{\circ} \mathrm{C}$ (未補正值, 文献值 $\left.{ }^{10}\right)^{0} 132$ $\left.{ }^{\circ} \mathrm{C}\right)$ を示し, 赤外吸収スペクトルにチオール基に基づく吸収を示 さなかった。また $\mathrm{pH} 4.5$ 酢酸緩衝溶液中に拈ける紫外吸収スぺ クトルは $283 \mathrm{~nm}$ に吸収極大を示し，得られたモル吸光係数は $289\left(\mathrm{l} / \mathrm{mol} \cdot \mathrm{cm}\right.$, 文献值 $\left.{ }^{10)} 273\right)$ であった。合成品の溶液 ( $\mathrm{pH} \mathrm{4.5)}$ は水銀電極を用いて $-1.4 \mathrm{~V}$ で定電位電解すると定量的に DTT を生成することをポーラログラフ法で確認した。すべての溶液の イオン強度は硝酸カリウムを用いて 0.5 に調整した。その他の試 薬は市肘品（特級）を用いた。

\section{3 実 験 結 果}

\section{1 直 流 波}

$3.1 .1 \mathrm{pH}$ の影響 : $\mathrm{pH}$ 2 12 の溶液中で OX-DTT は 2 段 の還元波を示した。より正電位側の波を第 1 波, それにつつくゆ っくりと立ち上がる明らかに非可逆な波を第 2 波とする（図 1 )。 $\mathrm{pH} 10$ 以上の塩基性溶液中では第 2 波の限界電流を生じる部分 （たとえば pH 10.12 の溶夜中で $-0.9 〜-1.10 \mathrm{~V}$ の間）に不 連続な変化をともなった極太波が現われたが，この極大波はゼラ チンなどの極大抑制剤により抑制された（すなわち OX-DTT の 濃度が $5 \times 10^{-4} \mathrm{~mol} / \mathrm{dm}^{3}$ のとき極大を抑制するのに $2 \times 10^{-3} \%$ のゼラチンを必要とした)。第 1 波の波高は溶液の $\mathrm{pH}$ 值の増加 とともにゆるやかに増大した。すなわち $\mathrm{pH} 4.5$ の溶液中におけ る $5 \times 10^{-4} \mathrm{~mol} / \mathrm{dm}^{3}$ の濃度の OX-DTT.の示す波高は $0.53 \mu \mathrm{A}$ であったが, $\mathrm{pH} 7.0,11.0$ の溶液中ではそれぞれ 0.9, $1.45 \mu \mathrm{A}$ と高い值を示した。

一方, 全波高は $\mathrm{pH} 2$ 12 の溶液中でほぼ一定の值 $(2.65 \pm$ $0.06 \mu \mathrm{A})$ を示した。第 1 波および第 2 波の半波電位 $\left(E_{1 / 2}\right)$ は溶 液の $\mathrm{pH}$ 值の增加とともに負電位に移行するのが認められた（図 2 )。このときの $\mathrm{pH}$ と $E_{1 / 2}$ の関係は第 1 波の場合（図 2-a) には三つの直線部分にわかれ，その傾きは $\mathrm{pH} \mathrm{2 \sim 8}$ の間では

10) W.W. Cleland, Biochemistry, 3, 480(1964).

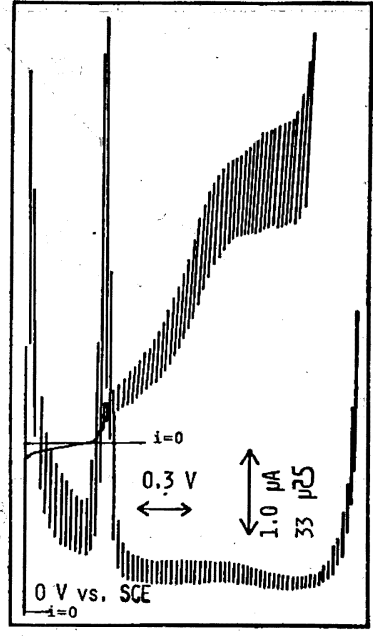

Fig. $1 \mathrm{AC}$ and $\mathrm{DC}$ polarograms of $5 \times 10^{-4} \mathrm{~mol} / \mathrm{dm}^{3} \mathrm{OX}-$ DTT in acetate buffer solution of $\mathrm{pH} 4.5$

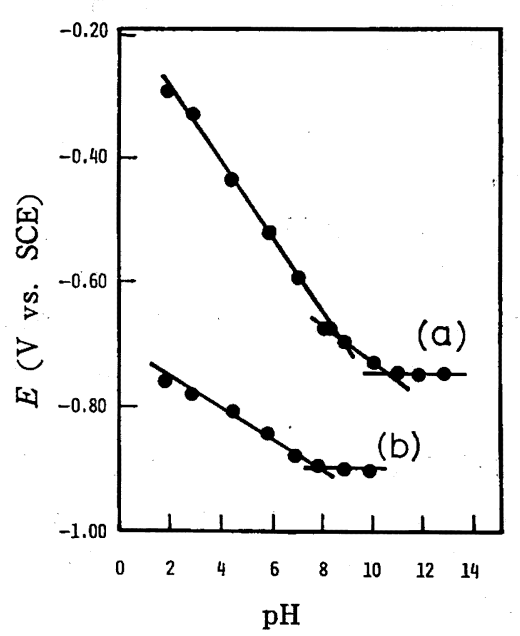

Fig. 2 Relations between half wave potentials of cathodic 1 st wave (a) and of cathodic 2 nd wave (b) of OX-DTT and $\mathrm{pH}$ of solutions

$-60 \mathrm{mV} / \mathrm{pH}, \mathrm{pH}$ 8 10.6 の間では $-30 \mathrm{mV} / \mathrm{pH}, \mathrm{pH} 10.6$ 以上で は $0 \mathrm{mV} / \mathrm{pH}$ を示した。これらの直線部分の交点における $\mathrm{pH}$ 值 （それぞれ 8.6 と 10.6） は前報で報告したDTT の $\mathrm{pH}-E_{\mathrm{d}}\left(E_{\mathrm{d}}\right.$ : DTT の陽極第 1 波の出現電位) の関係から得られた值 (9.3 と 10.6）と比較するととくに DTT の第 1 の酸解離定数と考えられ る值は大きく偏っている。また第 2 波の場合にも $E_{1 / 2}$ は溶液の $\mathrm{pH}$ 值の増大とともに負電位に移行した。

3.1 .2 濃度の影響: 第 1 波の波高は図 3 に示すように OXDTT の濃度の増加とともに非直線的に増大する。この傾向は酸 性の溶液中よりも塩基性の溶液中でいちじるしい（図 3-b)。一 方，第 2 波の波高（全波高で求めた）は濃度に比例した(図 3-a)。 第 1 波の $E_{1 / 2}$ は濃度が $3 \times 10^{-4} \mathrm{~mol} / \mathrm{dm}^{3}$ 以上の場合にはほぼ一 定の值（たとえば pH 4.5 の溶液中で $-0.430 \mathrm{~V}$ vs. SCE）を示 したが，これよりも低濃度の場合では濃度の低下とともにわずか に正電位側に移行した（すなわち $\mathrm{pH} 4.5$ の溶液中で OX-DTT の濃度が $1 \times 10^{-4} \mathrm{~mol} / \mathrm{dm}^{3}$ の場合には $E_{1 / 2}=-0.410 \mathrm{~V}$ を示し た。

3.1 .3 温度の影響: 第 1 波の温度係数は $25^{\circ} \mathrm{C}$ におて $\mathrm{pH}$ 


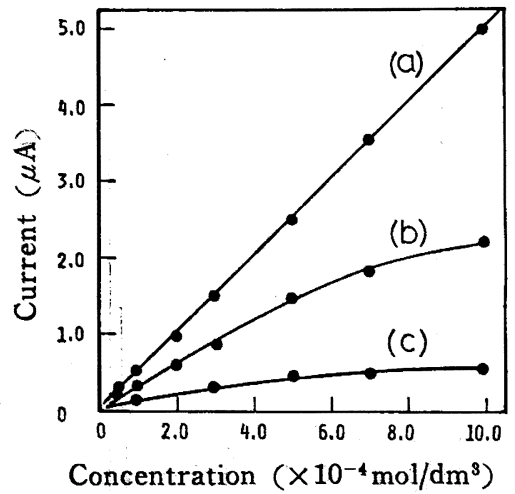

Fig. 3 Dependence of wave heights on the concentration of OX-DTT and DTT

(a) : 2 nd wave height of OX-DTT in solution of $\mathrm{pH}$ 4: 5

(b) : 1 st wave height of OX-DTT in solution of pH 11.0

(c) : 1 st wave height of OX-DTT in solution of $\mathrm{pH} 4.5$

4. 5，7.0 および 11.0 の溶液中でそれぞれ 5.5，4.2，および $2.7 \% / \mathrm{deg}$ ときわめて大きな值を示した。しかしょり低温 $\left(15^{\circ} \mathrm{C}\right.$ 以下) の領域では波高の温度係数はきわ的さく， pH 4.5 の 溶液中において $10^{\circ} \mathrm{C}$ での值は $0.1 \% / \mathrm{deg}$ であった。一方，第 2 波（全波高で求めた）の場合にはその温度係数は同じく $\mathrm{pH}$ $4.5,7.0,11.0$ の溶液中 $25^{\circ} \mathrm{C}$ で $1.71,1.68$ および $1.39 \%$ $\operatorname{deg}$ であった。

3.1 .4 電流-時間曲線： $\mathrm{pH} 4.5$ の溶液中でそれぞれ $-0.44 \mathrm{~V}$ および $-1.27 \mathrm{~V}$ における電流一時間曲線 ( $i-t$ 曲線) を図 4 に示 す(このときの電位, $-0.44 \mathrm{~V}$ は第 1 波の限界電流, $-1.27 \mathrm{~V}$ は第 2 波の限界電流の平坦部に対応する電位である)。得られた $i-t$ 曲線の対数解析を行なったところ $i=A \cdot t^{K}$ における指数項 $(K)$ は第 1 波 $(-0.44 \mathrm{~V})$ における $i-t$ 曲線からは 0.60 , 第 2 波 $(-1.27 \mathrm{~V})$ に拈ける $i-t$ 曲線からは 0.27 が得られた。以上 の結果から，第 1 波は反応律速波の性質をもっていることを示 し，一方，第 2 波は拡散電流に相当するものと考えられる ${ }^{11 。}$ 。事 実水銀柱の高さ $(h)$ の変化による実験の結果では第 1 波の波高 はほほ $h$ に比例し，第 2 波の場合には波高（全波高）は $h^{1 / 2}$ に 比例した。

3.1.5 界面活性戍の影響: OX-DTT の還元波, とくに第 1 波 は共存する界面活性剂の影響を強く受ける。すなわち $\mathrm{pH} 4.5$ の 溶液中で $5 \times 10^{-3} \%$ のゼラチンが共存すると OX-DTT $\left(5 \times 10^{-4}\right.$ $\left.\mathrm{mol} / \mathrm{dm}^{3}\right)$ の第 1 波の波高はもとの $0.53 \mu \mathrm{A}$ から $0.21 \mu \mathrm{A}$ へと 低下し，ゼラチンの濃度がさらに増加して $10^{-2} \%$ になると波高 は $0.09 \mu \mathrm{A}$ へと低下した。しかし全波高（-1.35 V で計測した） のときにはぜラチン濃度が $10^{-2} \%$ のときでも波高はもとの值 $(2.66 \mu \mathrm{A})$ とほぼ同一の值 $(2.64 \mu \mathrm{A})$ を示した。

\section{2 交 流波}

pH 1〜12 の溶液中で直流第 1 波に対応した交流波（図 1 , 以 下交流第 1 波之呼ぶ）の波高は溶液の $\mathrm{pH}$ 值の増加とともにゆる やかに增大するのが認められるが，この現象はすでに上に述べた

11) L. Meites, "Polarographic Techniques", 2 nd ed., John wiley \& Sons, London (1965) p.114.

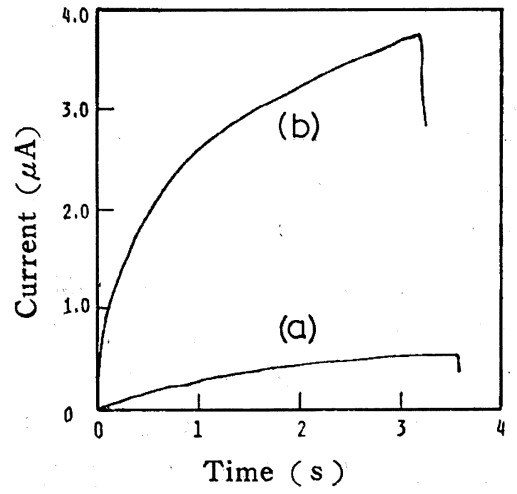

Fig. 4 Current-time curves measured at $-1.27 \mathrm{~V}$ vs. $\operatorname{SCE}$ ( a ) and $-0.44 \mathrm{~V}$ vs. SCE (b) of the cathodic current of $5 \times 10^{-4} \mathrm{~mol} / \mathrm{dm}^{3}$ OX-DTT in acetate buffer solution of $\mathrm{pH} 4.5$

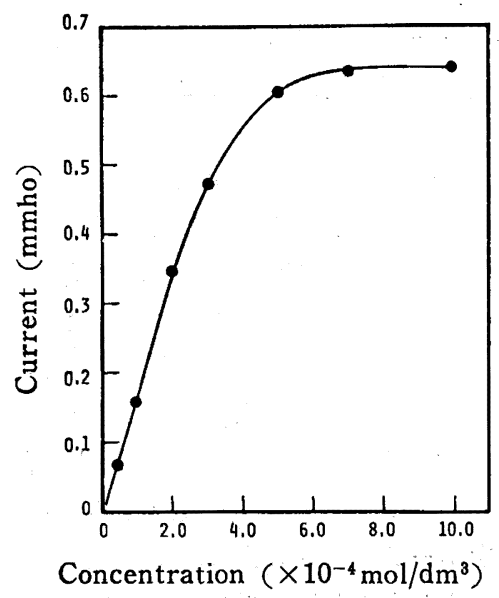

Fig. 5 Dependence of $A C$ wave height on the concentration of OX-DTT in $\mathrm{pH} 4.5$ acetate buffer solution

直流第 1 波に批ける波高と $\mathrm{pH}$ の関係（図 3-b, c) に対応してい るものと考えられる。交流第 1 波の頂点電位 $\left(E_{\mathrm{P}}^{\mathrm{AC}}=-0.46 \mathrm{~V}\right.$, $\mathrm{pH} 4.5)$ は対応する直流第 1 波の $E_{1 / 2}(-0.430 \mathrm{~V}, \mathrm{pH} 4.5)$ と 一致せず $E_{1 / 2}$ よりも䄪 $30 \mathrm{mV}$ ほど負電位に認められた。また 交流第 1 波の半值幅は $\mathrm{pH} \mathrm{2,4.5}$ および 11.0 の溶液中でそれ ぞれ 30，45 および $60 \mathrm{mV}$ であった。またその波高は濃度の增 加とともに比例したが，濃度が $6 \times 10^{-4} \mathrm{~mol} / \mathrm{dm}^{3}$ 以上になるとは ぼ一定の飽和値を示した（図 5 )。一方，直流第 2 波に対応する 明瞭な交流波は観察されなかった（図 1)。しかし直流第 2 波の 限界電流に対応する電位 ( $\mathrm{pH} 4.5$ の溶液中で $-0.95 \sim-1.4 \mathrm{~V}$ 付近）では交流波の微少な変化 (1〜2 $\mu$ ひ增加)が認められた。

\section{3 サイクリックボルタンメトリー}

$5 \times 10^{-4} \mathrm{~mol} / \mathrm{dm}^{3}$ の濃度の OX-DTT を含む $\mathrm{pH} 4.5$ の酢酸緩 衝溶液中で HMDE を用いて行なったサイクリックボルタンメト リーの結果を図 6 および表 1 に示す。このとき HMDE はあらか じめ試料溶液中で一定時間（これを初期保持時間， $t_{\mathrm{ex}}$ と呼ぶ） 一定の電位（これを掃引開始電位， $E_{0}$ と呼ぶ）にたもったのち 電位の掃引を開始した。以下とくにことわらないかぎり $t_{\mathrm{ex}}=70$ 秒, $E_{0}=0 \mathrm{~V}$ とし, 電位掃引の幅は $0 \sim-1.5 \mathrm{~V}$ の間で行なっ た。電位掃引の方向は $E_{0}$ からまず負電位側すなわち還元方向に 
Table 1 Peak potentials $\left(E_{\mathrm{p}}\right)$ and currents $\left(i_{\mathrm{p}}\right)$ appeared at the cyclic voltammetry of OX-DTT $\left(5 \times 10^{-4} \mathrm{~mol} / \mathrm{dm}^{2}\right)$ in buffer solution of $\mathrm{pH} 4.5$

\begin{tabular}{|c|c|c|c|c|c|c|}
\hline & . & \multicolumn{3}{|c|}{ Reduction $\left._{\text {waves }}{ }^{a}\right)$} & \multicolumn{2}{|c|}{ Oxidation waves ${ }^{b)}$} \\
\hline By the & 1 st scanning $\left\{\begin{array}{l}E_{\mathrm{p}}(\mathrm{V} \text { vs. } \mathrm{SCE}) \\
i \mathrm{~A})\end{array}\right.$ & -0.455 & , & -1.10 & -0.295 & -0.460 \\
\hline By the & 2nd scanning $\left\{\begin{array}{l}E_{\mathrm{p}}(\mathrm{V} \text { vs. SCE) } \\
i_{\mathrm{p}}(\mu \mathrm{A})\end{array}\right.$ & $\begin{array}{l}-0.382 \\
11.7\end{array}$ & $\begin{array}{c}-0.475 \\
4.0\end{array}$ & $\begin{array}{c}-1.10 \\
1.2\end{array}$ & $\begin{array}{l}-0.295 \\
2.5\end{array}$ & $\begin{array}{l}-0.460 \\
\quad 3.1\end{array}$ \\
\hline $\begin{array}{l}\text { a) } \\
\text { b) }\end{array}$ & $\begin{array}{l}\text { Waves caused by the cathodic } \\
\text { Waves caused by the anodic po }\end{array}$ & $\begin{array}{l}\text { scannin } \\
\text { canning. }\end{array}$ & & & & \\
\hline
\end{tabular}

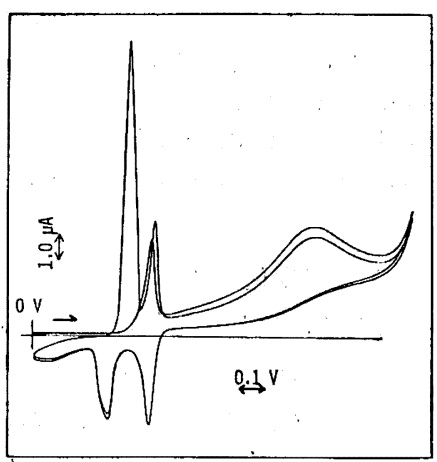

Fig. 6 Cyclic voltammetry of OX-DTT $\left(5 \times 10^{-4} \mathrm{~mol} / \mathrm{dm}^{3}\right)$ in $\mathrm{pH} 4.5$ acetate buffer solution

The HMDE was pre-equilibrated in stirred solution for $1 \mathrm{~min}$ and potential scanning rate was $0.1 \mathrm{~V} / \mathrm{s}$.

掃引し（これを(第 1 回の）陰極方向の掃引と呼ぶ）》ぎに折り 返し電位からもとの電位側すなわち酸化方向 (これを(第 1 回の) 陽極方向の掃引と呼ぶ）に掃引した。以後第 2 回の陰極方向の掃 引，第 2 回の陽極方向の順に掃引を行なった。OX-DTT の第 1 回の陰極方向の掃引の場合二つの波 (頂点電位 $E_{\mathrm{p}}=-0.455$, $-1.10 \mathrm{~V}$ vs. SCE, $\mathrm{pH} 4.5,5 \times 10^{-4} \mathrm{~mol} / \mathrm{dm}^{3} \mathrm{OX}-\mathrm{DTT}$, 電位 掃引速度 $V=0.1 \mathrm{~V} / \mathrm{s}$ ) また第 2 回の陰極方向の掃引以後の之き には基本的には三つの波（表 $1, E_{\mathrm{p}}=-0.382,-0.475,-1.10$ V) が現われた。

第 1 回の陰極方向の電位掃引における第 1 波 $\left(E_{\mathrm{p}}=-0.455 \mathrm{~V}\right)$ はやや非対称な波形を示し，その半值幅は約 $40 \mathrm{mV}$ であった。 第 1 波の波高とその面積（すなわち電流-時間曲線の積分値であ り電気量に相当する）は OX-DTT の濃度が $5 \times 10^{-4} \mathrm{~mol} / \mathrm{dm}^{3}$ の 溶液中 ( $\mathrm{pH} \mathrm{4.5)} \mathrm{で} V$ が $0.1 \mathrm{~V} / \mathrm{s}$ のとき $t_{\mathrm{ex}}$ とともに增大し, $t_{\mathrm{ex}}=70$ 秒以上になるとほぽ一定の值 (すなおち波高 $3.2 \mu \mathrm{A}$, 電気量 $3.55 \times 10^{-6} \mathrm{C}$ ) を示した。つぎた $t_{\mathrm{ex}}=70$ 秒で OX-DTT の濃度が二定 $\left(5 \times 10^{-4} \mathrm{~mol} / \mathrm{dm}^{3}\right)$ の溶液中で $V を$ 変化して実験し たところ $V$ が $20 \sim 200 \mathrm{mV} / \mathrm{s}$ の間で第 1 波の波高は $V$ に比例し た。第 2 波 $\left(E_{\mathrm{p}}=-1.10 \mathrm{~V}\right)$ は半值幅が約 $320 \mathrm{mV}(V=0.1 \mathrm{~V} / \mathrm{s})$ のきわめてゆるやかな波形を示し，その波高は溶液中の OX-DTT 濃度に比例した。また第 2 波はOX-DTT の濃度が $5 \times 10^{-4} \mathrm{~mol} /$ $\mathrm{dm}^{3}$ の溶液中で $V$ が $20 \sim 200 \mathrm{mV} / \mathrm{s}$ の範囲でその波高は $V^{1 / 2}$ に比例寸るが， $E_{\mathrm{p}}$ は $V$ に無関係であった。

第 2 回以後の陰極方向の電位掃引のときに現われた第 1 波. $\left(E_{\mathrm{p}}\right.$ $=-0.382 \mathrm{~V})$ の波高は濃度の減少とともに低下し, $2 \times 10^{-4} \mathrm{~mol} /$ $\mathrm{dm}^{3}$ のとさこの波は二つの波 $\left(E_{\mathrm{p}}=-0.35,-0.38 \mathrm{~V}, V=0.1\right.$ $\mathrm{V} / \mathrm{s}$ ) に分離した。この現象は $5 \times 10^{-4} \mathrm{~mol} / \mathrm{dm}^{3}$ の濃度でVが比 較的遅い $(50 \mathrm{mV} / \mathrm{s})$ のとさでも観察された。さらにこれら二つ の波は OX-DTT の濃度が $10^{-4} \mathrm{~mol} / \mathrm{dm}^{3}$ 以下の場合には観察さ
れなかった。また第 2 回以後の陰極方向の電位掃引によって観察 された第 2 波 $\left(E_{\mathrm{p}}=-0.475 \mathrm{~V}\right)$ は左右非対称 ( $E_{\mathrm{p}}$ より負電位側 で急激に電流が低下した）の波形を示し，OX-DTT の濃度が $10^{-4} \sim 5 \times 10^{-4} \mathrm{~mol} / \mathrm{dm}^{3}$ の間でその波高は濃度に無関係にほぼ一 定の值 $(4.0 \mu \mathrm{A}, V=0.1 \mathrm{~V} / \mathrm{s})$ を示した。むたこの波高はV $V$ か $20 \sim 200 \mathrm{mV} / \mathrm{s}$ の間で $V$ に比例した。 $E_{\mathrm{p}}$ は $V$ が大きくなると わずかに負電位に移行した。同じく第 3 波: $\left(E_{\mathrm{p}}=-1.10 \mathrm{~V}\right)$ は第 1 回の陰極方向への電位掃引のときに現われた第 2 波と同じ波形 および $E_{\mathrm{p}}$ を示したが, 電位の掃引をくり返すと波高はしたいに 減少する傾向にあった。

つぎに陽極方向の電位掃引のときには第 1 回和よび第 2 回㑴引 以後のときにも二つの波 $\left(E_{\mathrm{p}}=-0.460 \mathrm{~V},-0.295 \mathrm{~V}, \mathrm{pH} 4.5\right.$, $\left.5 \times 10^{-4} \mathrm{~mol} / \mathrm{dm}^{3} \mathrm{OX}-\mathrm{DTT}, V=0.1 \mathrm{~V} / \mathrm{s}\right)$ を示した。そしてこれ らの波の $E_{\mathrm{p}}$ は電位掃引只回数によっても変化しなかった。負電 位側からみて第 1 波 $\left(E_{\mathrm{p}}=-0.460 \mathrm{~V}\right)$ は左右非対称の波形を示 し，その波高は OX-DTT の濃度とともに増大するが $3 \times 10^{-4}$ $\mathrm{mol} / \mathrm{dm}^{8}$ 以上で一定の飽和值 (3.1 $\left.\mu \mathrm{A}, V=0.1 \mathrm{~V} / \mathrm{s}\right)$ を示した。 第 1 波の波高と $V$ の関係を求めたところ濃度が $10^{-4}, 5 \times 10^{-4}$ $\mathrm{mol} / \mathrm{dm}^{3}$ のいずれの場合にも $V$ が $20 \sim 150 \mathrm{mV} / \mathrm{s}$ の間で波高は $V$ に比例した。しかし $E_{\mathrm{p}}$ は $V$ が大きくなるとわずかに負電位 側に移行した。つぎに第 2 波 $\left(E_{\mathrm{p}}=-0.295 \mathrm{~V}\right)$ は $V$ が 20〜200 $\mathrm{mV} / \mathrm{s}$ の間で波高は $V^{1 / 2}$ に比例したが $E_{\mathrm{p}}$ はほほ一定であった。 また $V=0.1 \mathrm{~V} / \mathrm{s}$ のとき OX-DTT の濃度が $2 \times 10^{-4} \sim 5 \times 10^{-4}$ $\mathrm{mol} / \mathrm{dm}^{3}$ の間でその波高は濃度とともに増大した。

電位掃引の速度が $10 \mathrm{mV} / \mathrm{s}$ 以下かまたは電位を一定にたもっ たときサイクリックボルタモグラム上の特定の電位領域すなお ち, OX-DTT の濃度が $5 \times 10^{-4} \mathrm{~mol} / \mathrm{dm}^{3}$ のときで電位掃引の方 向が陰極方向のときには $-0.38 \sim-0.55 \mathrm{~V}$ の間で，また陽極方 向に掃引したときには $-0.55 \sim-0.36 \mathrm{~V}$ の間で, またこれらの 電位で HMDE の電位を手動で一定たたもうたときでも記錄計の ペンが不規則に振動する現象が観察された。同じよらな現象は DTT のみの溶液中でも $-1.0 \mathrm{~V}$ から陽電位方向に電位掃引し たとき $-0.55 〜-0.33 \mathrm{~V}$ の間です観察された。

\section{4 考察}

Kolthoff ら $^{6)}$ はシスチンンの第 1 波について検討を行ない，水銀 プール電極を用いてシスチンーシスティンを種々の割合で含む溶 液中で電位と電流をプロットして得た標準酸化還元電位 $\left(E^{0}=\right.$ $+0.07 \mathrm{~V}$ vs. NHE) の值と, 鉄(II)-シスチン錯体を用いて分光 光度法で得た $E^{0}$ の值 $(+0.08 \mathrm{~V} \text { vs. } \mathrm{NHE})^{12}$ とがよく一致し ていることから第 1 波の電極反応をつぎのように考えた。

12) N. Tanaka, I. M. Kolthoff, W. Striks, J. Am. Chem. Soc., 77, 2004(1955). 
$\mathrm{RSSR}+\mathrm{Hg} \rightleftarrows(\mathrm{RS})_{2} \mathrm{Hg}$

ここで生じた $(\mathrm{RS}){ }_{2} \mathrm{Hg}$ はすみやかに還元され，

$$
\left(\mathrm{RS}_{j_{2}} \mathrm{Hg}+2 \mathrm{H}^{+}+2 e^{-} \rightleftarrows 2 \mathrm{RSH}+\mathrm{Hg}\right.
$$

(1)，（2）式から全体として

$$
\mathrm{RSSR}+2 \mathrm{H}^{+}+2 e^{-} \rightleftarrows 2 \mathrm{RSH}
$$

ここで, RSSR はシスチン, RSH はシスティンを示すものと する。

すなわち直流第 1 波は水銀の接触作用による可逆なものである

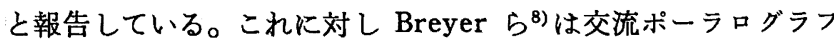
法を用いてシスチンの波を検討し異なった結論を得た。すなわち $\mathrm{pH} 4$ 以上の溶液中で直流第 1 波に対応する交流波の頂点電位 $\left(E_{\mathrm{p}}^{\mathrm{AC}}\right)$ が直流波の $E_{1 / 2}$ よりもつねに $30 \sim 40 \mathrm{mV}$ 負電位を示す こと，また直流波の対数プロットの傾き， $\Delta E_{1 / 2} / \Delta \mathrm{pH}, E_{1 / 2}-\log$ $\left(i_{\mathrm{d}} / 2\right)$ の傾きの理論值がそれぞれ $29.5 \mathrm{mV}, 59 \mathrm{mV} / \mathrm{pH}, 29.5$ $\mathrm{mV}$ であるのにくらべ, 実験值が $37 \sim 43 \mathrm{mV}, 72 \mathrm{mV} / \mathrm{pH}, 56$ $\mathrm{mV}$ となっていることから直流第 1 波に対応する交流波は(3)式 に対応するものではなく（4)および( 5 )式に示すように電極表 面に吸着したシスチン分子の可逆な電子授受反応によるものであ ると結論した。

$$
\begin{aligned}
& \mathrm{RSSR} \longrightarrow[\mathrm{RSSR}]_{\mathrm{ad}} \\
& {[\mathrm{RSSR}]_{\mathrm{ad}}+2 \mathrm{H}^{+}+2 e^{-} \rightleftarrows 2 \mathrm{RSH}}
\end{aligned}
$$

ここで, $[\mathrm{A}]_{\mathrm{ad}}$ は A が電極表面に吸着した状態を示すものと する。

すなわちこの場合には電極表面における吸着の過程 (( 4 )式) が律速段階となっている。また $E_{\mathrm{p}}^{\mathrm{AC}}$ と $E_{1 / 2}$ のズレから電極表 面に RSH よりも RSSR の方が多く吸着していることを推定し, 還元の結果生じた RSH は電極表面からすみやかに除かれるため, 電極表面は吸着物で完全におおわれることがなく，このため直流 第 1 波は濃度依存性を示す，と結論した。シスチンに対するその 後の研究 ${ }^{13) ~ 15) ~}$ はおむに水銀の挙動について行なわれたが，最近 Bard 5 ${ }^{15)}$ はサイクリックボルタンメトリーを用いてシスチン, システィンの電極反応を検討し， RSSR の還元にはその水銀塩 $(\mathrm{RS})_{2} \mathrm{Hg}$ が中間体になることを示し，水銀への吸着力について は $\mathrm{RSHg} \gg \mathrm{RSSR}>\mathrm{RSH}$ の順であることを報告している。

OX-DTT の直流第 1 波 $\left(E_{1 / 2}=-0.430 \mathrm{~V}, \mathrm{pH} 4.5\right)$ は上に示 した実験結果，すなわち波高の温度係数， $i-t$ 曲線，水銀柱の高 さの変化などから反応律速波の性質を示していることは明らかで ある。OX-DTT の還元波の形状，珄質はともにリポ酸の還元波 よりもむしろシスチンの還元波に類似していることが認められ る。また直流第 1 波に対応する還元の過程においてはシスチンの 場合と同様に復極剤すなわち OX-DTT が溶液中から水銀電極表 面に吸着する過程((4)式)が律速段階と考えるならば，第 1 波の 示す諸性質のらち波高が濃度に対して非直線的に増加することお よび溶液の $\mathrm{pH}$ による波高の変化（図3）などの現象はつぎのよ らに説明することができる。すなわち濃度に対する非直線性は電 極界面における吸着反応(C 4)式)の非直線性によるものと説明さ

13) W. Lee, Biochem. J., 121, 563(1971).

14) I. R. Miller, J. Teva, J. Electroanal. Chem., 36, 157 (1972).

15) M. Stankovich, A. J. Bard, ibid., 75, 487(1977).
Table 2 AC polarographic peak potentials $\left(E_{\mathrm{p}}^{\mathrm{AC}}\right)$ and currents $\left(i_{\mathrm{p}}\right)$ with reference to the half wave

\begin{tabular}{|c|c|c|c|}
\hline Redox system & $E_{1 / 2}(\mathrm{~V}$ vs. $\mathrm{SCE})$ & $E_{\mathrm{p}}^{\mathrm{AC}}(\mathrm{V}$ vs. $\mathrm{SCE})$ & $i_{\mathrm{p}}$ \\
\hline DTT & -0.434 & -0.430 & $4.49^{a)}$ \\
\hline OX-DTT & -0.430 & -0.464 & $0.61^{a)}$ \\
\hline $\begin{array}{l}\text { Dihydrolipoic } \\
\text { acid }\end{array}$ & -0.52 & -0.52 & $2.49^{b)}$ \\
\hline Lipoic acid & -0.52 & -0.52 & $2.56^{b)}$ \\
\hline
\end{tabular}
potentials $\left(E_{1 / 2}\right)$ of corresponding DC wave (1st wave) of thiol-disulfide redox svstems in acetate buffer solution of $\mathrm{pH} 4.5$

a) $5 \times 10^{-4} \mathrm{~mol} / \mathrm{dm}^{3}$ of depolarizer present. Currents are shown in mmo.

b) $4 \times 10^{-4} \mathrm{~mol} / \mathrm{dm}^{3}$ of depolarizer present. Currents are shown in $\mathrm{mA}$, data in ref. 9).

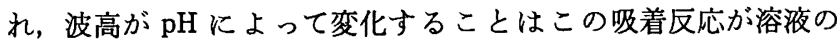
$\mathrm{pH}$ に依存しているために生じた現象と思われる。

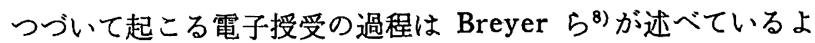
らに可逆なもの(( 5 )式)とは必らずしも考えられない。なぜなら これは表 2 から判定されるように酸化体 (OX-DTT), 還元体 (DTT) のおのおのの溶液中で現われる交流波の波高については 前者は後者にくらべていちじるしく低く，また $E_{\mathrm{\mu}}^{\mathrm{AC}}$ がたがいに 一致していないからである（これに対してリポ酸の場合には酸化 体，還元体の双方の波高および $E_{\mathrm{p}}^{\mathrm{AC}}$ はよく一致し，その電極反 応が可逆なものであることが十分説明されている)。すなわち水 銀電極に吸着した OX-DTT の電子授受の過程は（6)式で示され るような非可逆な反応と解釈される（シスチン，システィンのと きと同じょうに OX-DTT, DTTを酸化体, 還元体の一般式 RSSR，RSH を用いて示すと)。

$$
[\mathrm{RSSR}]_{\mathrm{gd}}+2 \mathrm{H}^{+}+2 e^{-} \longrightarrow 2 \mathrm{RSH}
$$

ここで, DTT の陽極波ポーラログラムの立ち上がり電位 $\left(E_{\mathrm{d}}\right.$ $=-0.44 \mathrm{~V}, \mathrm{pH} 4.5$ ) が OX-DTT のポーラログラフ波（第 1 波）の立ち上がり電位 $(-0.40 \mathrm{~V}, \mathrm{pH} 4.5)$ よりも負電位側にあ ることから(6)式の反応につつう RSH(すなわち DTT) から前 報2)で述べたよらな水銀塩の形成される反応（(7)式,この反応 は可逆性が高い2)）が始まることが予想される。

$$
\mathrm{RSH}+\mathrm{Hg} \rightleftarrows \mathrm{RSHg}+\mathrm{H}^{+}+e^{-}
$$

しかし実際にはこの反応が進行していないのは(7)式の反応が 連続して起こる RSSR の吸着 ((4)，（6)式）によって抑えられ たためと説明される。

また上に示したサイクリックボルタンメトリーの現象はつぎの よらに説明することができる。すなわち第 1 回陰極方向の電位掃 引によって現われた還元第 1 波 $\left(E_{\mathrm{p}}=-0.455 \mathrm{~V}\right)$ は，波高も面 積も $t_{\mathrm{ex}}$ とともに增大し $t_{\mathrm{ex}}=70$ 秒で一定の飽和値を示す。こ の一定值に達した波高が $V$ の変化に対し直線的に比例することか ら主として水銀電極に吸着した OX-DTT（単分子膜を形成して いるものと考えられる）の非可逆的な還元による波とすることが できる16)。

つぎに OX-DTT の直流第 2 波 $\left(E_{1 / 2}=-0.91 \mathrm{~V}, \mathrm{pH} 4.5\right)$ で あるが，その波高は溶液中の OX-DTT に直線的に比例し，波高

16) E. Laviron, J. Electroanal. Chem., 52, 355, 395(1974). 
の温度係数, $i-t$ 曲線の対数解析, 水銀柱の高さの変化の実耠結 果から明らかに桩散律速波の性質を示している。またその波高は 同じ pH 4.5 の酥酸緩衙溶液中で測定したDTT の陽極第 2 波の 波高 $\left.\left(2.67 \mu \mathrm{A}, \mathrm{DTT}: 5 \times 10^{-4} \mathrm{~mol} / \mathrm{dm}^{3}\right)^{2}\right)$ とほぼ同し值 $(2.65$ $\mu \mathrm{A}$, OX-DTT : $\left.5 \times 10^{-4} \mathrm{~mol} / \mathrm{dm}^{3}\right)$ を示した。したがって第 2 波 は溶液中の OX-DTT の DTT への還元反応 (( 8$)$ 式) に対応し た非可逆な波と考えられる。

$$
\mathrm{OX}-\mathrm{DTT}+2 \mathrm{H}^{+}+2 e^{-} \longrightarrow \mathrm{DTT}
$$

このことは第 1 回の陰極方向の電位掃引のときのサイクリック ボルタモグラムに現われた第 2 波 $\left(E_{\mathrm{p}}=-1.10 \mathrm{~V}\right)$ の波高が濃度 および $V^{1 / 2}$ に比例すること，またこの波の $E_{\mathrm{p}}$ に対応した電位に 交流波が現われないことともよく対応する。

つぎに折り返し電位から陽極方向に電位掃引を行なったサイク リックボルタモグラムに現われた第 1 波 $\left(E_{\mathrm{p}}=-0.460 \mathrm{~V}\right)$ はそ の波形が左右非対称で波高, $E_{\mathrm{p}}$ が掃引回数に無関係にほぼ一定 の值を示し， $V$ に比例することなどからこの波は OX-DTT の還 元 ((8)式)によって生じた DTT の水銀塩の単分子膜の形成反 応 $((7) \text { 式 })^{2)}$ によるものと思われる。同じく陽極方向の電位掃引 に拈将る第 2 波 $\left(E_{\mathrm{p}}=-0.295 \mathrm{~V}\right)$ は波高が OX-DTT の溶液濃 度および $V^{1 / 2}$ に比例していることなどから，上に述べた DTT の水銀塩の単分子被膜の存在のもとでさらに水銀塩の多重層が形 成される水銀の溶出反応による波と考兄られる22。

つぎに第 2 回の陰極方向の電位掃引のサイリックボルタモグラ 厶に現われた第 1 波 $\left(E_{\mathrm{p}}=-0.382 \mathrm{~V}\right)$ は第 1 回の陰極方向の電 位掃引のときには現われなかった。また波高が濃度とともに增加 するが，濃度およびVの条件によっては波形が变化（二つの波に わかれる)ことなどからこの波は第 1 回の陽極方向の電位掃引に よって（(8)式にしたがって)生じた DTT の水銀塩の多重層が (吸着した単分子層の存在のもとで) 還元される反応に基つく波 と考光られる。またこの波が $2 \times 10^{-4} \mathrm{~mol} / \mathrm{dm}^{3}$ の濃度で二つの波 にわかれたのは水銀表面に存在する DTT の水銀塩の多重層が均 一な層でないために複雑な反応が生じているものと推定される。

つぎに第 2 回以後の陰極方向の電位掃引のときに現われた第 2 波 $\left(E_{\mathrm{p}}=-0.475 \mathrm{~V}\right)$ はその波高が $V$ に比例し, 濃度に無関係に ほぼ一定の值を示すことなどからおる DTT の水銀塩の単分子 吸着層の還元に基づく波と考学られる。またこの波の波高が電位 の掃引回数に無関係にほぼ一定であるが， $E_{\mathrm{p}}$ が掃引回数によっ て少しずつではあるが負電位に移行したのは還元される物質が水 銀塩のみでなく溶液からの OX-DTT の還元も一部生じているた めと推定される。第 3 波 $\left(E_{\mathrm{p}}=-1.10 \mathrm{~V}\right)$ は第 1 回の陰極方向の

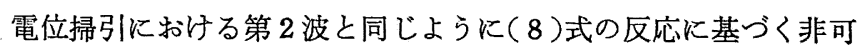
逆な還元波と考えられる。

上に述べたように第 1 回の陰極方向の電位掃引のとき現われた 第 1 波 $\left(E_{\mathrm{p}}=-0.455 \mathrm{~V}\right)$ の電極反応を初期電圧 $E_{0}(=0 \mathrm{~V})$ に拉 いて電極表面に吸着した OX-DTT の還元によるものと推定し た。したがって第 1 波の示す面積すなわち還元に要した電気量か ら HMDE に吸着した OX-DTT 1 分子の占有面積を求めること が可能になるはずである。実験は $5 \times 10^{-4} \mathrm{~mol} / \mathrm{dm}^{3}$ の OX-DTT を用い， $E_{0}$ を $0 \mathrm{~V}$ にたるち $t_{\mathrm{ex}}$ を変化してサイクリックボルタ モグラムを記録し第 1 波の面積を眓上積分した（ただし基底電流 は $-0.36 \mathrm{~V}$ と $-0.55 \mathrm{~V}$ に打ける電流值を結ぶ線とした)。 $t_{\mathrm{ex}}$
$=90$ 秒に打いて面積 (電気量) として $3.55 \times 10^{-6} \mathrm{C}$ が得られた。 HMDE の表面積 $\left(0.065 \mathrm{~cm}^{2}\right)$ を用いて吸着した OX-DTT 1 分 子の占有面積 $(S)$ を計算したところ, $S=5.8 \times 10^{3}\left(\mathrm{~nm}^{2}\right)$ であ った。この值は前報2)で報告した DTT の直流波 (陽極第 1 波) の波高を用いて Brdička 式により計算した DTT の水銀塩 1 分 子の占有面積 $\left(4.9 \times 10^{2} \mathrm{~nm}^{2}\right)$ とよく一致した。以上の結果から DME 表面に打ける吸着の形態として DTT-水銀塩の場合には水 銀, OX-DTT の場合には硫黄の原子を電極表面にむけて配向し ていることが推定される。

つぎに電位掃引の速度がきわめて遅いときか，または一定電位 のときサイクリックボルタモグラムに現われた不規則な電流の振 動の現象はつぎのように解釈される。すなわちこの振動が生してて いる電位領域が電極表面に吸着した OX-DTT の還元していると ころ, および DTT の水銀塩の単分子膜が形成していると考えら れる電位に対応していることから, これらの電位領域で電極の表 面では(4)，(6)式による吸着怙よび還元反応，(7)式に上る酸化 反応，さらには遅い反応ではあるが前報2)で述べたような RSSR の生成による反応なども同時に生じた結果 RSSR の吸着層と $\mathrm{RSHg}$ の吸着層が相互に影響をおよぼし合う形となり,その結果 として電流が不安定となり不規則な振動が観察されるものと考兄 られる。

\section{5 結 論}

OX-DTT は $\mathrm{pH}$ 2 12 の溶液中で 2 段の還元波を示した。第 1 波 $\left(E_{1 / 2}=-0.430 \mathrm{~V}\right.$ vs. SCE, pH 4.5) は反応律速波, 第 2 波 $\left(E_{1 / 2}=-0.91 \mathrm{~V}, \mathrm{pH} 4.5\right)$ は拡散律速波の性質を示した。交 流波としては直流第 1 波の $E_{1 / 2}$ よりも約 $30 \mathrm{mV}$ 負電位に頂点 電位を示す波が認められたが, 直流第 2 波に対応する波は認めら れなかった。また交流波の頂点電位 $\left(E_{\mathrm{p}}^{\mathrm{A}} \mathrm{C}\right)$, 波高 $\left(i_{\mathrm{p}}^{\mathrm{A}} \mathrm{C}\right)$ は $\mathrm{DTT}$ の溶液中で観察された $E_{\mathrm{p}}^{\mathrm{AC}}, i_{\mathrm{p}}^{\mathrm{AC}}$ に一致しなかった（表 2 )。し たがって直流第 1 波の電極反応は(4)，（6)式の反応に基づく電 極表面に吸着した OX-DTT の非可逆な還元反応と考えられる。 第 2 波は溶液中の OX-DTT の非可逆な還元波 (( 8 ) 式) と考え られる。

サイクリックボルタモグラム (CV) については, 陰極方向に電 位掃引したとき現われた第 1 波 $\left(E_{\mathrm{p}}=-0.455 \mathrm{~V}\right)$ は主として掃 引開始前の静止電圧 $(O V)$ で水銀電極に吸着した OX-DTT の 還元による波と解釈され，第 2 波 $\left(E_{\mathrm{p}}=-1.10 \mathrm{~V}\right)$ は $(8)$ 式の電 極反応注対応した波と考学られる。陽極方向に電位掃引したとき 現われた二つの波の第 1 波 $\left(E_{\mathrm{p}}=-0.460 \mathrm{~V}\right)$ は DTT の水銀塩 の単分子形成の反応 ( $(7)$ 式) による波と考光られ，第 2 波 $\left(E_{\mathrm{p}}\right.$ $=-0.295 \mathrm{~V})$ は同じく水銀塩の多重層形成反応によるものと考 えられた。電位掃引をふたたびくり返したときに院極方向の電位 掃引では三つの波が現われたが，第 1 波 $\left(E_{\mathrm{p}}=-0.382 \mathrm{~V}\right)$ は上 に述べた水銀塩の多重層が単分子膜の存在のもとで還元されるた めに生じた波と考劣られる。そして第 2 波 $\left(E_{\mathrm{p}}=-0.475 \mathrm{~V}\right)$ は 水銀塩の単分子膜の還元による波と解积された。第 3 波は第 1 回 掃引のときの第 2 波に相当し（8)式の反応による波と考劣られ る。

第 1 回の陰極方向の電位掃引で現われた第 1 波の電極反応を電 極の表面に吸着したOX-DTT の非可逆な還元波としたが，第 1 波の示す面積（すなわち電気量）と電極の表面積から電極に吸着 
した OX-DTT 1 分子の占有面積を求めたところ $5.8 \times 10^{8}\left(\mathrm{~nm}^{2}\right)$ が得られた。この值は前報で報告した DTT の水銀塩の吸着によ る占有面積 $\left(4.9 \times 10^{3} \mathrm{~nm}^{2}\right)$ とよく一致した。

また電位揥引の速度が $10 \mathrm{mV} / \mathrm{s}$ より遅いとき CV の特定の電 位領域で電流が不規則に振動する現象が観察されたが，これは
（4），(6)，（7 式の酸化-還元反応または前報で述べたような OX-DTT の生成反応により電極表面において OX-DTT の吸着 層と DTT の水銀塩の吸着層が相互に影響をおよぼし合った結果 電流が不安定となって現われた現象と解糆される。

\section{Po arographic Studies of Oxidized, Cyclic Disulfide Form of Dithiothreitol ${ }^{\dagger}$ \\ Seiki Yamaguchi*, Tsutomu Tsukamoto and Mitsugi Senda** \\ Department of Chemistry, Osaka Medical College; Sawaragi-cho, Takatsuki-shi 569 Japan \\ ** Department of Agricultural Chemistry, Kyoto University ; Kitashirakawa, Sakyo-ku, Kyoto-shi 606 Japan}

OX-DTT (trans-1,2-dithiane-4,5-diol, a cyclic disulfide form of dithiothreitol) gave two cathodic waves at DME in the buffer solution of $\mathrm{pH} 2$ to 12 . The first wave $\left(E_{1 / 2}=-0.430 \mathrm{~V}\right.$ vs. SCE, at $\mathrm{pH} 4.5)$ had a nature of reaction-controlled current and the second wave $\left(E_{1 / 2}=\right.$ $-0.91 \mathrm{~V}$ vs. SCE, $\mathrm{pH} 4.5)$ showed a nature of diffusion-controlled current. In AC polarography, a single AC wave of irreversible nature was observed at $E_{\mathrm{p}}^{\mathrm{AC}}=-0.460 \mathrm{~V}, \mathrm{pH} 4.5$. The polarographic behavior of OX-DTT was interpreted as follows. The first DC polarographic wave height is controlled by the rate of adsorption of OX-DTT to the DME surface (eq. (4)) and the adsorbed OX-DTT is irreversibly reduced to dithiothreitol (DTT) as shown in eq. (6). The second DC wave is due to the irreversible reduction of OX-DTT to DTT (eq. (8)) at DME. Cyclic voltammetric behavior of OX-DTT at HMDE was also interpreted in terms of eq. (4), (6) and (8). Current oscillation phenomenon observed at mercury electrode when the voltage scan rate is very slow (less than $10 \mathrm{mV} / \mathrm{s}$ ) seems due to a complicated oxidation and reduction process associated with the adsorption of OX-DTT, DTT and mercury salt of DTT.

\footnotetext{
$\dagger$ Electrochemical Behavior of Dithiothreitol and Its Cyclic Disulfide Form on Mercury Electrode. II.
} 